\title{
Front Matter: Volume 9444
}

, "Front Matter: Volume 9444," Proc. SPIE 9444, International Seminar on Photonics, Optics, and Its Applications (ISPhOA 2014), 944401 (21 January 2015); doi: 10.1117/12.2185074

Event: International Seminar on Photonics, Optics, and Applications 2014, 2014, Sanur, Bali, Indonesia 


\title{
PROCEEDINGS OF SPIE
}

\section{International Seminar on Photonics, Optics, and lts Applications (ISPhOA 2014)}

\author{
Aulia Nasution \\ Editor
}

14-15 October 2014

Sanur, Bali, Indonesia

Organized by

Department of Engineering Physics - FTI

Institut Teknologi Sepuluh Nopember (Indonesia)

Sponsored by

The Optical Society (United States)

PT Telekomunikasi Selular (Indonesia)

PT Len Industri (Indonesia)

PT Sigma Cipta Caraka (Indonesia)

Published by

SPIE 
The papers included in this volume were part of the technical conference cited on the cover and title page. Papers were selected and subject to review by the editors and conference program committee. Some conference presentations may not be available for publication. The papers published in these proceedings reflect the work and thoughts of the authors and are published herein as submitted. The publisher is not responsible for the validity of the information or for any outcomes resulting from reliance thereon.

Please use the following format to cite material from this book:

Author(s), "Title of Paper," in International Seminar on Photonics, Optics, and Its Applications (ISPhOA 2014), edited by Aulia Nasution, Proceedings of SPIE Vol. 9444 (SPIE, Bellingham, WA, 2015) Article CID Number.

ISSN: 0277-786X

ISBN: 9781628415599

\section{Published by}

\section{SPIE}

P.O. Box 10, Bellingham, Washington 98227-0010 USA

Telephone +1 3606763290 (Pacific Time) · Fax +1 3606471445

SPIE.org

Copyright @ 2015, Society of Photo-Optical Instrumentation Engineers.

Copying of material in this book for internal or personal use, or for the internal or personal use of specific clients, beyond the fair use provisions granted by the U.S. Copyright Law is authorized by SPIE subject to payment of copying fees. The Transactional Reporting Service base fee for this volume is $\$ 18.00$ per article (or portion thereof), which should be paid directly to the Copyright Clearance Center (CCC), 222 Rosewood Drive, Danvers, MA 01923. Payment may also be made electronically through CCC Online at copyright.com. Other copying for republication, resale, advertising or promotion, or any form of systematic or multiple reproduction of any material in this book is prohibited except with permission in writing from the publisher. The CCC fee code is 0277-786X/15/\$18.00.

Printed in the United States of America.

Publication of record for individual papers is online in the SPIE Digital Library.

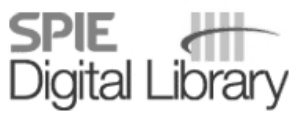

SPIEDigitalLibrary.org

Paper Numbering: Proceedings of SPIE follow an e-First publication model, with papers published first online and then in print. Papers are published as they are submitted and meet publication criteria. A unique citation identifier (CID) number is assigned to each article at the time of the first publication. Utilization of CIDs allows articles to be fully citable as soon as they are published online, and connects the same identifier to all online, print, and electronic versions of the publication. SPIE uses a six-digit CID article numbering system in which:

- The first four digits correspond to the SPIE volume number.

- The last two digits indicate publication order within the volume using a Base 36 numbering

system employing both numerals and letters. These two-number sets start with $00,01,02,03,04$, $05,06,07,08,09,0 A, 0 B \ldots$. OZ, followed by 10-1Z, 20-2Z, etc.

The CID Number appears on each page of the manuscript. The complete citation is used on the first page, and an abbreviated version on subsequent pages. 


\title{
Contents
}

\author{
vii Authors \\ ix Conference Committee \\ xi Introduction \\ xiii Sponsors
}

INVITED SESSION

944402 Compact one-lens fluorescence microscope using CMOS image sensor (Invited Paper) [9444-21]

944403 Semiconductor lasers for versatile applications from global communications to on-chip interconnects (Invited Paper) [9444-65]

944404 Rigorous characterization of photonic devices by finite element method (Invited Paper) [9444-66]

944405 Photonics engineering: snapshot applications in healthcare, homeland security, agriculture, and industry (Invited Paper) [9444-67]

944406 Identifying the best chalcogenide glass compositions for the application in mid-infrared waveguides (Invited Paper) [9444-10]

\section{PHOTONICS AND OPTICS APPLICATIONS}

944407 Large ring laser gyroscopes: towards absolute rotation rate sensing [9444-62]

944408 TOPAS-based humidity insensitive polymer planar Bragg gratings for temperature and multi-axial strain sensing [9444-19]

944409 Activating neurons by light in free-moving adult flies [9444-4]

9444 OA Liquid level sensing based on laser differential confocal detectors [9444-16]

9444 OB Evaluating compact SAR polarimetry for tropical forest monitoring [9444-35]

9444 OC Interferometric processing of C-band SAR data for the improvement of stand age estimation in rubber plantation [9444-9]

9444 OD Radial line method for rear-view mirror distortion detection [9444-49]

9444 OE Design of low cost smart infusion device [9444-43] 
9444 OF Tapered fiber optic sensor for potassium detection in distilled water [9444-60]

9444 OG Web camera as low cost multispectral sensor for quantification of chlorophyll in soybean leaves [9444-50]

$9444 \mathrm{OH} \quad$ Mapping system for the surface temperature in the ljen Crater by Landsat-8 imagery with supervised image segmentation method based on fuzzy logic [9444-55]

\section{PHOTONICS MATERIALS}

$9444 \mathrm{Ol} \quad$ Fundamental and harmonic soliton mode-locked erbium-doped fiber laser using singlewalled carbon nanotubes embedded in poly (ethylene oxide) film saturable absorber [9444-26]

9444 OJ Polarization dependent terahertz generation efficiency by optical rectification in $\mathrm{LiNbO}_{3}$ [9444-31]

9444 OK Al-doped MgZnO/p-AIGaN heterojunction and their application in ultraviolet photodetectors [9444-11]

$9444 \mathrm{OL} \quad$ Fabrication and characterization of cuprous oxide solar cell with net-shaped counter electrode [9444-36]

$9444 \mathrm{OM}$ The effect of spectrum range limitation to the efficiency of $\mathrm{Al} 0.3 \mathrm{Ga} 0.7 \mathrm{As} / \mathrm{GaAs} / \mathrm{InP} / \mathrm{Ge}$ multijunction solar cells: a simulation case [9444-44]

$94440 \mathrm{~N} \quad$ Spectral calibration of the coded aperture spectra imaging system [9444-8]

944400 Co-sensitized natural dyes potentially used to enhance light harvesting capability [9444-46]

9444 OP Identify paraffin-embedded brain glioma using terahertz pulsed spectroscopy [9444-32]

$9444 \mathrm{OQ} \quad$ Modeling and experiment of dye-sensitized solar cell with vertically aligned ZnO nanorods through chemical bath deposition [9444-51]

9444 OR Mechanical and optical characterization of bio-nanocomposite from pineapple leaf fiber material for food packaging [9444-53]

\section{PHOTONICS DEVICE DEVELOPMENTS}

9444 OS Fabrication of 1D photonic crystal by sol-gel method for tuning the emission of CdSe colloidal quantum dot [9444-30]

9444 OT Optical response characteristics of strained uniform fiber Bragg grating using laser diode [9444-42]

9444 OU Phase matching analyses of anti-Stokes pulses with four wave mixing in birefringence photonic crystal fibers [9444-37] 
$9444 \mathrm{OV}$ Using a telecommunication-grade single mode patchcord as an optical extensometer based on bending loss [9444-17]

9444 OW Load effect on an SMS fiber structure embedded in a high-density polyethylene [9444-58]

9444 0X Research on key technologies of high repetition rate optical frequency comb [9444-15]

9444 OY Optical system design of the snapshot imaging spectrometer using image replication based on Wollaston prism [9444-6]

$94440 Z$ Preliminary design of land displacement-optical fiber sensor and analysis of observation during laboratory and field test [9444-18]

944410 SMS fiber structure with a multimode fiber graded index type for a temperature measurement using an intensity-based interrogation system [9444-59]

944411 Design of GaN-based S-bend Y-branch power splitter with MMI structure [9444-41]

944412 16-channel arrayed waveguide grating (AWG) demultiplexer design on SOI wafer for application in CWDM-PON [9444-27]

944413 Broadband millimeter-wave electro-optic modulator using multi patch antennas for picocell radar networks [9444-28]

944414 Local density of optical states of an asymmetric waveguide grating at photonic band gap resonant wavelength [9444-5]

\section{POSTER SESSION}

944415 A mid-IR optical emission spectrometer with a PbSe array detector for analyzing spectral characteristic of IR flares [9444-29]

944416 Colour harmony of two colour combinations in clothes matching [9444-12]

944417 Development of optical inspection system for detecting malfunctions of digital micromirror device [9444-34] 
Proc. of SPIE Vol. $9444944401-6$

Downloaded From: https://www.spiedigitallibrary.org/conference-proceedings-of-spie on 26 Apr 2023 Terms of Use: https://www.spiedigitallibrary.org/terms-of-use 


\section{Authors}

Numbers in the index correspond to the last two digits of the six-digit citation identifier (CID) article numbering system used in Proceedings of SPIE. The first four digits reflect the volume number. Base 36 numbering is employed for the last two digits and indicates the order of articles within the volume. Numbers start with 00, 01, 02, 03, 04, 05, 06, 07, 08, 09, OA, OB...0Z, followed by 10-1Z, 20-2Z, etc.

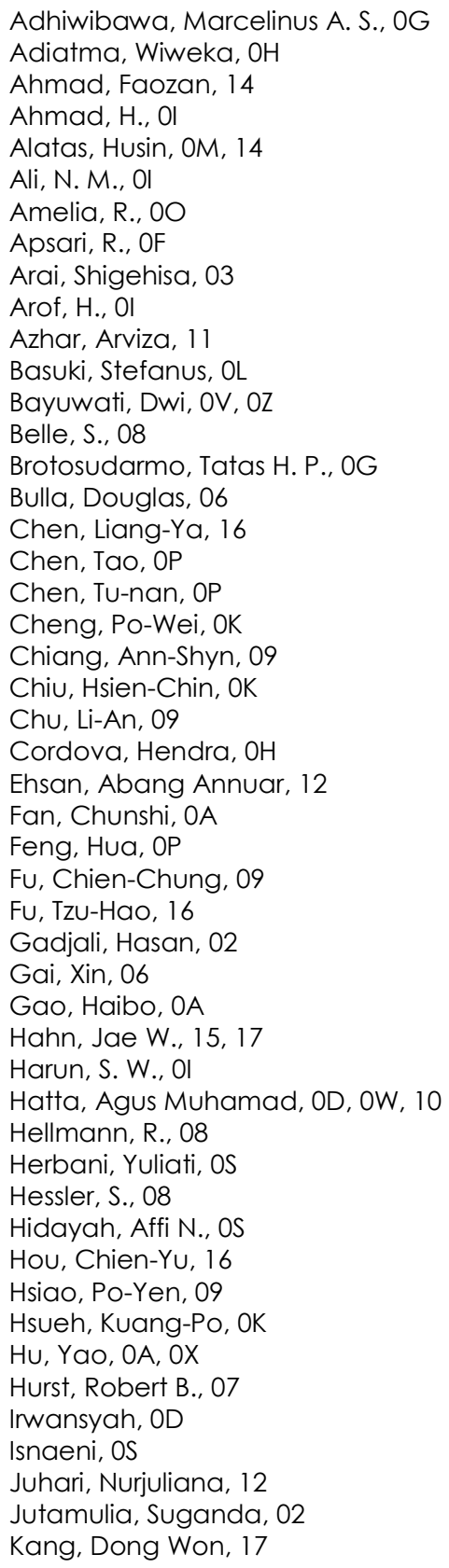

Kang, Minwook, 15, 17

Kanno, Atsushi, 13

Kawanishi, Tetsuya, 13

Kejalakshmy, N., 04

Koentjoro, Sekartedjo, OW, 10

Kusumawardhani, Apriani, $\mathrm{OD}, \mathrm{OH}$

Lee, Wondong, 15, 17

Li, Fei, OP

Li, Wei-yan, OY

Li, Ze-Ren, OJ, OP

Li, Zhao, OP

Lin, Wen-Yen, OK

Lin, Yen-Yin, 09

Liu, Qiao, OJ, OP

Liu, Yangyang, ON

Luther-Davies, Barry, 06

LV, Qunbo, ON, OY

Madden, Steve, 06

Meng, Kun, OJ, OP

Menon, P. Susthitha, 12

Min, Huang, ON, OY

Mufarrikha, Ainun, 10

Nikmatin, Siti, OR

Ou, Li-Chen, 16

Pangaribuan, Julinda, $\mathrm{OL}$

Panuju, Dyah R., OC

Paull, David J., OC

Pei, Lin-lin, ON, OY

Prasetyo, Kurnia Wiji, OR

Prilianti, Kestrilia R., OG

Pujiyanto, OF

Purnamaningsih, Retno Wigajatri, OE, OT, 11

Puspita, Ika, OW

Putri, Kirana Y., OS

Rabeendran, Nishanthan, 07

Rahmah, Fitri, OD, OW

Rahman, B. M. A., 04

Risanti, Doty Dewi, 00, 0Q

Rosdin, R. Z. R. R., Ol

Rosenberger, M., 08

Rudwiyanti, Jerry R., OR

Saputra, Yohanes David, OE

Sawitri, D., 00

Schmauss, B., 08

Schreiber, K. Ulrich, 07

Setiawan, Yonathan E., OG

Setijono, Heru, OD

Setiono, Andi, OT

Shaari, Sahbudin, 12 
Sheu, Jinn-Kong, OK

Su, Xueqiong, 06

Suliyanti, Maria M., OS

Sumaryada, Tony I., OM, 14

Sumriddetchkajorn, Sarun, 05

Syafutra, H., OM

Tanjung, M., OF

Trisasongko, Bambang $\mathrm{H} ., \mathrm{OB}, \mathrm{OC}$

Uranus, Henri P., OL

Wahyuni, E. S., OM

Wahyuono, Ruri Agung, $0 Q$

Waluyo, Tomi Budi, OV, OZ

Wang, Jianwei, ON, OY

Wang, Li, OU

Wang, Rongping, 06

Wang, Ting, 06

Wang, Xiang, $0 X$

Wells, Jon-Paul R., 07

Wicaksono, Sungging Haryo, 16

Widiyatmoko, Bambang, OT, $\mathrm{OZ}$

Wijayanto, Yusuf Nur, 13

Wu, Ming-Chin, 09

Yang, Zhiyong, 06

Yasin, M., OF

Yedi, Dwi Arso, OR

Yeh, Yu-Hsiang, OK

Yulianto, Nursidik, OS

Zarei, A., Ol

Zhan, $\mathrm{Yi}, \mathrm{OU}$

Zhang, Li, OA, OX

Zhao, Jian-heng, OP

Zhong, Sen-Cheng, OJ, OP

Zhu, Li-Guo, OJ, OP 


\section{Conference Committee}

Conference Chairs

Aulia Nasution, General Chair, Institut Teknologi Sepuluh Nopember (Indonesia)

Agus Muhammad Hatta, Co-Chair, Institut Teknologi Sepuluh Nopember (Indonesia)

Patronage

Triyogi Yuwono, Institut Teknologi Sepuluh Nopember (Indonesia)

Bambang L. Widjiantoro, Institut Teknologi Sepuluh Nopember (Indonesia)

Totok Soehartanto, Institut Teknologi Sepuluh Nopember (Indonesia)

Advisory Committee

Bambang Hidajat, Indonesian Academy of Science (Indonesia)

Tjia May On, Indonesian Optical Society (Indonesia)

Andrianto Handojo, National Research Council (Indonesia)

Steering Committee

Sekartedjo Kuntjoro, Institut Teknologi Sepuluh Nopember

(Indonesia)

Dhany Arifianto, Institut Teknologi Sepuluh Nopember (Indonesia)

Agus Rubiyanto, Institut Teknologi Sepuluh Nopember (India)

John E. Batubara, University of Pelita Harapan (Indonesia)

Harith Bin Ahmad, Photonics Research Center (Malaysia)

Sulaiman Wadi Harun, Photonics Research Center (Malaysia)

Suganda Jutamulia, University of Northern California (United States)

Sar Sardy, University of Al Azhar (Indonesia)

Bambang Widiyatmoko, Indonesian Institute of Sciences (Indonesia)

Purnomo Sidi Priambodo, University of Indonesia (Indonesia)

Retno Wiagajtri Purnamaningsih, University of Indonesia (Indonesia)

Hakim Malasan, Institut Teknologi Bandung (India)

Endang Juliastuti, Institut Teknologi Bandung (Indonesia)

Gea Oswah Fatah Parikesit, University Gadjah Mada (Indonesia)

Henri Putra Uranus, University of Pelita Harapan (Indonesia)

Retna Apsari, Universitas Airlangga (Indonesia)

Hery Suyanto, University of Udayana (Indonesia)

Azhar Zam, University of California, Davis (United States)

Heru Setijono, Institut Teknologi Sepuluh Nopember (Indonesia) 
Program Committee

Sekartedjo Kuntjoro, Institut Teknologi Sepuluh Nopember (Indonesia)

Dhany Arifianto, Institut Teknologi Sepuluh Nopember (Indonesia)

Agus Rubiyanto, Institut Teknologi Sepuluh Nopember (India)

Harith Bin Ahmad, Photonics Research Center (Malaysia)

Sulaiman Wadi Harun, Photonics Research Center (Malaysia)

Suganda Jutamulia, University of Northern California (United States)

Sar Sardy, University of Al Azhar (Indonesia)

Erning Wihardjo, Krida Wacana Christian University (Singapore)

Hedwig Rinda, University Bina Nusantara (India)

Satria Zulkarnaen Bisri, University of Groningen (Netherlands)

Bambang Widiyatmoko, Indonesian Institute of Sciences (Indonesia)

Purnomo Sidi Priambodo, University of Indonesia (Indonesia)

Retno Wiagajtri Purnamaningsih, University of Indonesia (Indonesia)

Hakim L. Malasan, Institut Teknologi Bandung (India)

Endang Juliastuti, Institut Teknologi Bandung (Indonesia)

Gea Oswah Fatah Parikesit, University Gadjah Mada (Indonesia)

Henri Putra Uranus, University of Pelita Harapan (Indonesia)

Retna Apsari, Universitas Airlangga (Indonesia)

Hery Suyanto, University of Udayana (Indonesia)

Azhar Zam, University of California, Davis (United States)

Ary Syahriar, University Al Azhar Indonesia (Indonesia)

Ayi Bahtiar, Padjajaran University (Indonesia)

Rongping Wang, The Australian National University (Australia)

Mohammed M. A. Fadhali, Ibb University (Yemen)

Mohammad Yasin, Universitas Airlangga (Indonesia)

Salah Aldeen Galal Abdulrhmann, Jazan University (Saudi Arabia)

Sunish J. Mathews, University College London (United Kingdom)

Mohammad Zulkifli, University of Malaya (Malaysia)

Danang Birowosuto, University Siswa Bangsa International (Japan)

Sarun Sumriddetchkajorn, NECTEC (Thailand)

Session Chairs

1 Photonics and Optics Applications

Agus Muhammad Hatta, Institut Teknologi Sepuluh Nopember (Indonesia)

2 Photonics Materials

Doty D. Risanti, Institut Teknologi Sepuluh Nopember (Indonesia)

3 Photonics Device Developments

Sekartedjo Kuntjoro, Institut Teknologi Sepuluh Nopember (Indonesia) 


\section{Introduction}

The International Seminar on Photonics, Optics, and Its Applications (ISPhOA 2014) was held 14-15 October 2014 in Sanur, Bali. It aimed to bring together students, scientists, and engineers involved in research and development of technologies related to photonics, optics, and its applications from colleagues of researchers and academicians, which come from diverse sub-topics in optics and photonics fields.

This event provided an opportunity to participants to disseminate their recent original research findings, discussing current issues, as well as exchange of ideas related to photonics and optics technologies. The event wished to promote the transfer of research and development outcomes into applications that match with societal and industrial needs, particularly the ones across nationwide and ASEAN regions.

I would like to thank all invited speakers that agreed to accept our invitation to share their novel and recent research achievements and expertise to other participants of the seminar. Many thanks also to the worldwide researchers and academicians who have sent their working papers to be shared and presented in the seminar forum. High appreciation is also dedicated to members of the technical committee, who helped us review and choose the submitted contributions that fulfil the scientific quality standards set for the seminar. We thank all of the sponsors from companies and societies in optics and photonics (ICO, OSA, SPIE, and InOS) that gave their valuable support to the successful organization of the seminar. Last but not least, many thanks to the university's management (in all its levels) for their total and endless support, and for facilitating the preparation and organization of the seminar.

Aulia Nasution 
Proc. of SPIE Vol. $9444944401-12$

Downloaded From: https://www.spiedigitallibrary.org/conference-proceedings-of-spie on 26 Apr 2023 Terms of Use: https://www.spiedigitallibrary.org/terms-of-use 


\section{Sponsors}

The Organizer of the ISPhOA 2014 would like to acknowledge contributions from our sponsoring partners, i.e.:

1. PT Telkomsel (as Platinum Sponsor)

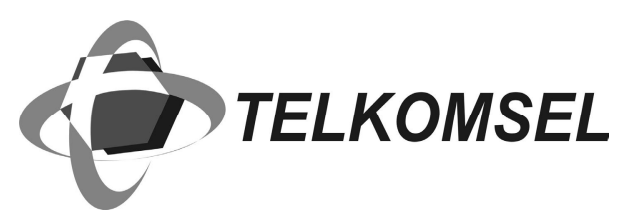

2. PT Len Industri (as Gold Sponsor)

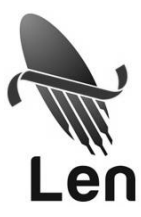

3. PT Telkomsigma (as Silver Sponsor)

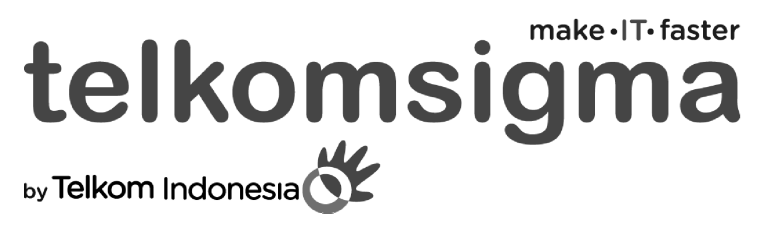


Proc. of SPIE Vol. $9444944401-14$

Downloaded From: https://www.spiedigitallibrary.org/conference-proceedings-of-spie on 26 Apr 2023 Terms of Use: https://www.spiedigitallibrary.org/terms-of-use 